海底地形急変部に基く内部境界面擾乱機構

\title{
Disturbing Mechanisms of Interface at Sea Bottom Irregularities
}

$\begin{array}{lll}\text { 東京理科大学 土木工学科、侏アイ・エヌ・エー新土木研究所 } & \text { 正員 } \bigcirc & \text { 柴田正和 } \\ \text { 東京理科大学 土木工学科 } & \text { 正員 } & \text { 大西外明 }\end{array}$

\section{1.はじめに}

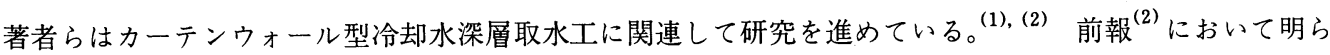
かになった内で重要な一つの点は上層淡水成分のゲート内への混入機構である。それは従来から考えられて いた ${ }^{(3),(4)}$ 密度流が安定な成層を保ったまま境界面がゲート下端より下るため上層淡水がその密度のままゲ 一ト内へ流入してくるという描像とは大いに異っており、取水量の増大に伴いゲート上流側のよどみ域に上 層と下層の混合による中間的な密度をもつ中間層が形成されその中間層と下層との境界面の不安定化に伴う 中間層成分の下層への連行により初めていわゆる上層成分のゲート内への混入が起こるというものである。 これは実験による観測結果であるが、水と油の二成層のように境界面の安定性が壊れず、上記の描像が当を 得ている場合でも、理論的に従来の限界取水の条件には問題のあることが指摘できる。従来の理論とは次の ようなものである。図 1-1 は安定な成層密度流の上層がゲート下端から混入する限界状態を示している。

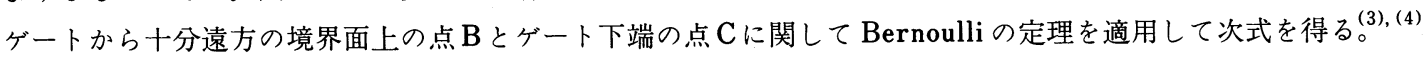

$$
\rho_{1} g(h-b)+\frac{1}{2} \rho_{2} u_{\mathrm{C}}{ }^{2}+\rho_{2} g b=\rho_{1} g\left(h-h_{2}\right)+\rho_{2} g h_{2}
$$

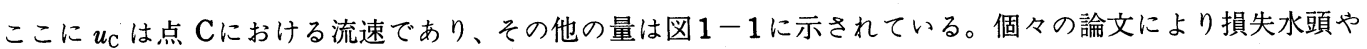
流線の曲率に基く圧力の補正等を考慮してはいるものの、実際にこの理論を応用する場合は本質的に式( 1 1 )を用いている。これから限界取水条件として次式を得る。

$$
\frac{h_{2}-b}{b}=\frac{1}{2} \alpha F_{i, b}^{2}
$$

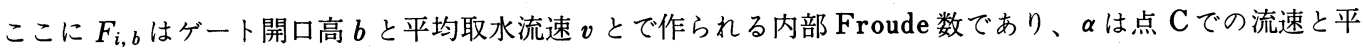
均取水流速 $v$ との補正係数である。この限界条件が意味を有するためには $\alpha$ が定数であるか一歩譲っても何

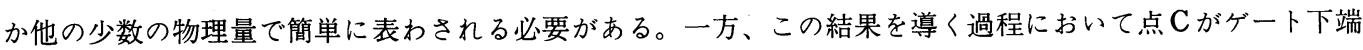

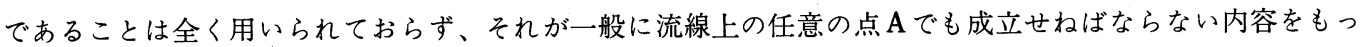
ていることは容易に理解される。そこで点 A と Bに対してBernoulli の式を立てると式 $(1-2)$ の代りに次 式を得る。

$$
\frac{h_{2}-y}{y}=\frac{1}{2} \alpha \frac{v^{2}}{\frac{\rho_{1}-\rho_{2}}{\rho_{2}} g y} \quad(1-3)
$$

或いは平均取水流速 $v$ を取水量 $Q$ と水路幅 $l$ を用いて表 わすと

$$
\frac{h_{2}-y}{y}=\frac{1}{2} \alpha \frac{Q^{2}}{\frac{\rho_{2}-\rho_{1}}{\rho_{2}} g l^{2}} \cdot \frac{1}{y^{3}}
$$

となる。ところが $\alpha$ が定数又は流れを全体的に特徵づけ るような量 (例えば内部 Froude 数とかReynolds 数) だ けに依る係数とすると式 $(1-4)$ は $\boldsymbol{y}$ の 3 次方程式とな

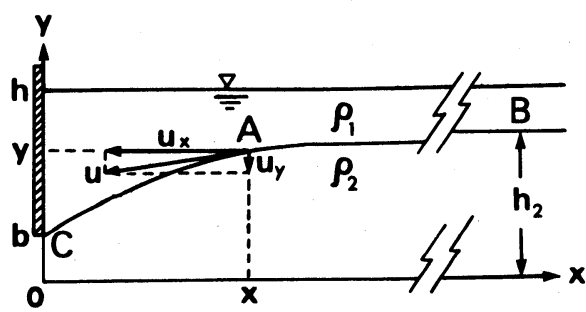

图 1-1 混合しない密度流のカーテンウォール 直上流での内部境界面と諸変数 
ことに矛盾する。即ち $\alpha$ は上述のような量ではなく鉛直座標 $y$ に explicit に依存する量であることが分る。 さて、そもそも $\alpha$ は点 $\mathrm{A}$ (式 $(1-2)$ では点 $\mathrm{C}$ ) における流速（の絶对值） $u$ と、 $\mathrm{A}$ と同じ $x$ 座標をもつ面で の平均取水流速 $v$ との間の補正係数として導入されたのであるが

$$
u^{2}=\alpha v^{2}
$$

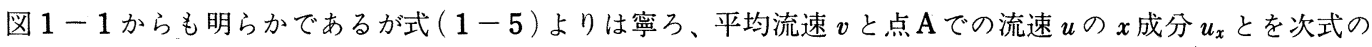
如く関係づける（ゲート直上流では $u_{y}$ を無視しえない）方が $\alpha$ の意味が理解されやすく、又それにより $\alpha$ 、 流れを全体的に特徵づける量と簡単に関係づけられる可能性をもってくると思われる。

$$
u_{x}^{2}=\alpha v^{2} \quad \text { i. e. } \quad u^{2} /\left(1+\left(\frac{d y}{d x}\right)^{2}\right)=\alpha v^{2}
$$

これを用いると境界面上の任意の点 $\mathrm{A}$ と分遠方の点 $\mathrm{B}$ に関するBernoulli の定理は

$$
\text { ， } h_{2}-y=\frac{1}{2} \alpha \frac{Q^{2}}{\frac{\rho_{2}-\rho_{1}}{\rho_{2}} g y^{2} l^{2}}\left(1+\left(\frac{d y}{d x}\right)^{2}\right)
$$

と表わすことができ、境界面形状は、微分方程式

$$
\frac{d y}{d x}=\sqrt{2 \frac{\rho_{2}-\rho_{1}}{\rho_{2}} \frac{g l^{2}}{\alpha Q^{2}}\left(h_{2}-y\right) y^{2}-1}
$$

を解くことにより求めることができる。

\section{2. 中間層の構造 (半経験的半公理論的公式)}

安定な二成層を形成している密度流もその二層間の相対流速の増加に伴って境界面に内部波が発生し、そ の内部波が不安定化することによって鋭い密度勾配を有する境界面を維持することができなくなり、遂には 中間層が形成されることはよく知られている。境界面が不安定になる条件に関しては種々の条件、情況の下 で多くの理論が展開され実験も試みられている。(1), (5), (6), (7), (8) 境界面の不安定化の条件を求める理論に於 ては定常状態に対する擾乱の相対的大きさが小さいとして非線形項を無視することができる(線形安定理論) が、その境界面が不安定化した結果生ずる最終状態に於ける密度流の構造については殆ど実験的研究又は現

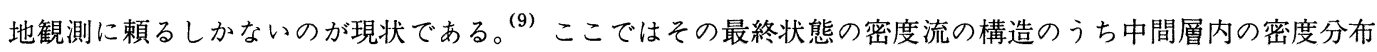

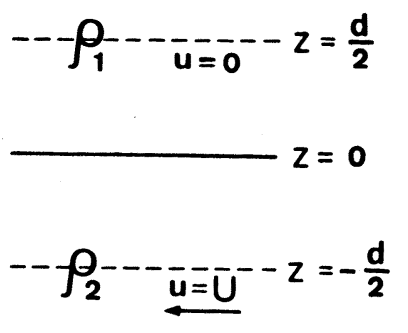

図 2-1 混合前の二層の密度と流速分布

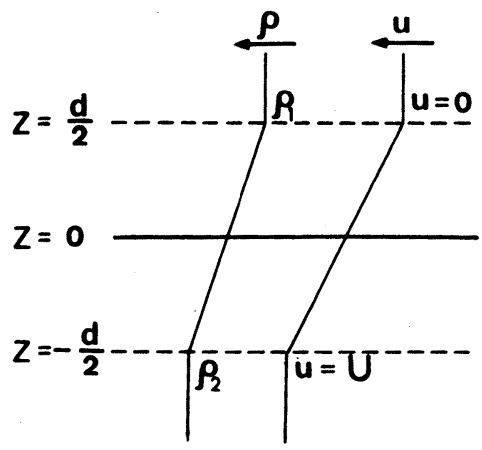

図 2-2 上下層の混合により生成された 中間層の構造 
及び流速分布は、実験又は観測事実から仮定し、これと一つの理論的仮説を用いて中間層の厚さを決定する ものである。

さて、初期状態の密度流は水平な境界面をもち、上層下層の密度は各々 $\rho_{1} 、 \rho_{2}$ であり、両層間にはUなる 相対流速があるとする。密度流の安定性には相対流速のみが関与するので簡単のために上層の流速を 0 、下 層の流速を $U$ として一般性を失わない。（図 2-1） これは単にいま求めている密度流の最終状態と上下層 の中間層から十分離れた位置での密度及び流速を指定することに対応する。この相対流速Uが前述の線形安 定理論又は実験で定まる限界流速を超えたときに遷移する最終状態の構造は中間層の厚さとその内での密度 及び流速分布で決定される。実在の中間層は上下層と明確な区別があるわけではなく密度、流速ともに連続 かつ滑らかに分布しているが、問題の精度を考えても又中間層の厚さを定義するためにも、上層中間層下層 の密度及び流速分布を図 $2-2$ のようにモデル化することが実験及び観測結果を反映するものとして十分で あると考えられる。即ち密度及び流速は中間層内で鉛直座標 $\boldsymbol{z}$ に関し線形に変化して各々上下層の密度及び 流速を連続的に接続しているというモデルを採る。これがこれから得られる公式の経験的側面である。その とき中間層の構造を決定するために残るパラメー夕は中間層の厚さ $d$ である。ここでは $d$ を決定するために 密度流系の全エネルギーの変化に着目する。その全エネルギーとは相対運動のエネルギーと浮力による位置 エネルギーの和を意味するものであるが、そもそも密度流の或る状態が不安定になるためには、その 状態に何らかの微少擾乱を与えたときに全エネルギーが減少しなければならない。即ちそのことが不 安定化の必要条件である。(1) 一方、このエネルギーの条件がそのまま安定性の限界条件（必要十分条件）に ならないのは、境界面の界面張力、粘性或いは更に複雑な機構が、より全エネルギーの小さい状態への遷移 を妨げるからである。それゆえ密度流が不安定になり他の状態へ遷移するには相対流速が更に増加してこれ らの安定化要因に打ち勝たなければならない。ここで採用する理論的仮説とは、一旦相対流速が密度成層流 を不安定化させるのに十分な大きさになり密度流の状 態の遷移が起ると、その遷移は全エネルギーが最小の 状態への遷移となる、というものである。これは凹凸 のある滑らかな斜面上にある球の問題に例えてみれば 次のようになる。(図 2-3) 図の球が初めI の位置 （状態）にあったとする。Iに比へ M、Fはこの場合重 力の位置エネルギー（密度流での全エネルギーに対応 する）が低い状態であるが球はポテンシャルの障壁 $\mathrm{A}$ の存在のため $\mathrm{M}$ 又は $\mathrm{F}$ に遷移できない。しかし球に運 動エネルギーを与えると球はIを中心に振動を始め $\mathrm{A}$ を越えるのに十分な運動エネルギーを得ると $\mathrm{M} に$ 向っ て状態の遷移を始める。この場合に前述の仮説に対応

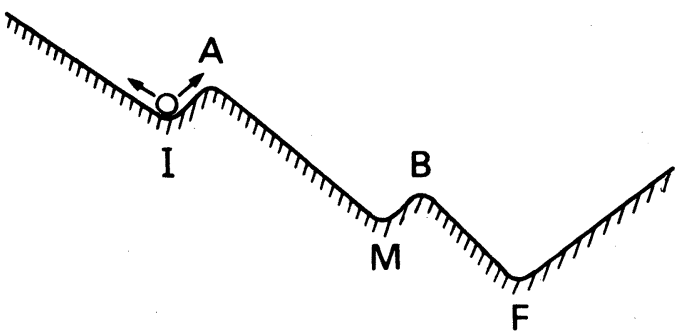

図 2-3 斜面上の球の状態とその間の遷移 する内容は、一旦球が I から状態の遷移を始めると中 間の状態 $\mathrm{M}$ に留ることなく位置エネルギー最小の状態 $\mathrm{F} に$ 迄落ちてゆくということである。この仮説を採用 すると中間層の厚さ $d$ は一意的に定まり上記のモデルによる中間層の構造は以下のように完全に決定される。

図 2-2の中間層の有している全エネルギーを単位水平面積当り $E$ とすると、密度及び流速分布 $\rho(z) 、$ $u(z)$ が次の形をとることを用いて、

$$
\begin{aligned}
& \rho(z)=\frac{\rho_{1}-\rho_{2}}{d} z+\frac{\rho_{1}+\rho_{2}}{2} \\
& u(z)=U\left(\frac{1}{2}-\frac{z}{d}\right)
\end{aligned}
$$

以下のように定まる。 


$$
\begin{aligned}
E & =\text { 位置エネルギー十運動エネルギー } \\
& =\int_{-\frac{d}{2}}^{\frac{d}{2}} d z \rho(z) g z+\int_{-\frac{d}{2}}^{\frac{d}{2}} d z \frac{1}{2} \rho(z) u^{2}(z) \\
& =\frac{1}{12}\left(\rho_{1}-\rho_{2}\right) g d^{2}+\frac{1}{24}\left(\rho_{1}+3 \rho_{2}\right) U^{2} d
\end{aligned}
$$

対応する部分が初期状態即ち図 2-1の状態にあったとき持っていた全エネルギー $E_{0}$ は同様な計算の結果

$$
E_{0}=\frac{1}{8}\left(\rho_{1}-\rho_{2}\right) g d^{2}+\frac{1}{4} \rho_{2} U^{2} d
$$

これから境界面が不安定になるための必要条件は次の如く得られる。即ち $E_{0}>E よ り$

$$
d<\frac{3 \rho_{2}-\rho_{1}}{\rho_{2}-\rho_{1}} \cdot \frac{U^{2}}{g}=\left(\frac{2 \rho_{2}}{\rho_{2}-\rho_{1}}+3\right) \frac{U^{2}}{g}
$$

また図 2-2 型の中間層で最も全エネルギーの小さい中間層の厚さは

$$
\frac{\partial}{\partial d}\left(E_{0}-E\right)=0
$$

より、次のように定まる。

$$
d=\left(\frac{\rho_{1}}{\rho_{2}-\rho_{1}}+\frac{3}{2}\right) \frac{U^{2}}{g}
$$

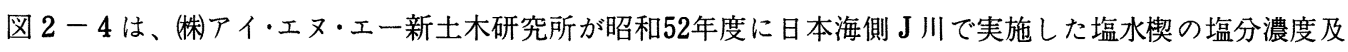

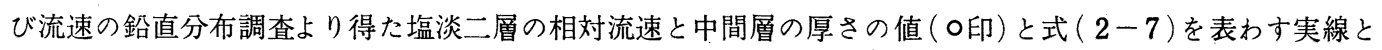
の関係を両対数表示で比較するものである。実在 河川での実測值にはモデル化した相対流速以外に 河床地形、支川の流入など多くの要因が影響を与 えるので、その間にバラツキがあるのは当然の結 果であるが、式 $(2-7)$ の実線は式中に実験定数 (adjustable parameter)を全く含んでいないこと に鑑み観測值をよく説明していると考えられる。

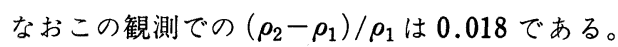
この中間層の厚さは Kelvin-Helmholtz 不安定の 限界波数 $k_{c}$ とも密接に関連していることが以上の 議論から理解できる。 ${ }^{(6)}$

$$
\begin{aligned}
k_{c} & =\frac{\left(\rho_{2}-\rho_{1}\right)\left(\rho_{2}+\rho_{1}\right)}{\rho_{1} \rho_{2}} \frac{g}{U^{2}} \\
& \simeq \frac{\rho_{2}-\rho_{1}}{\rho_{1}} \cdot \frac{2 g}{U^{2}} \simeq \frac{2}{d}
\end{aligned}
$$

既述の如くこれ以上密度及び流速分布を精密化す

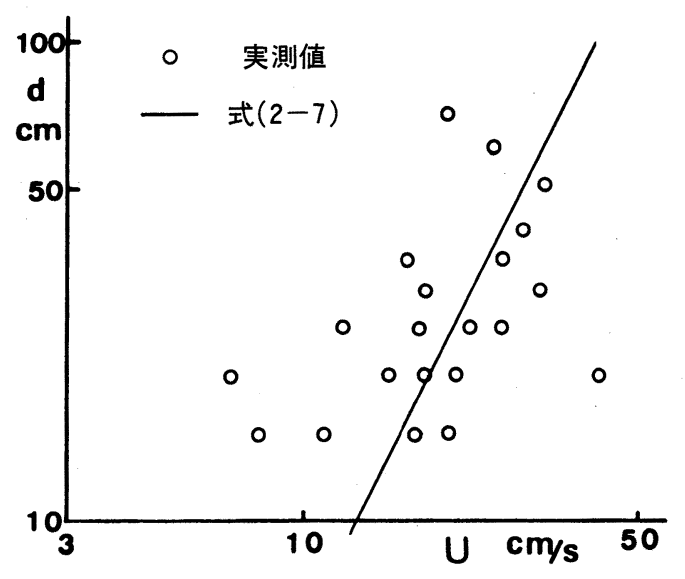

図 2-4 密度流の相対流速と中間層の厚さ

ることはあまり意味があるとは考えられないが、 本法は任意の $\rho(\boldsymbol{z})$ 及び $u(z)$ に関しても適用可能 であることは明らかである。

\section{3 . 海底地形急変部における密度流の流況}

河口で塩水楔が発達している場合のように「開放系」としての密度流では相対流速が臨界値を超えると 2 節 で述べたような中間層が生成されることが考えられるが、我々が当面問題としているカーテンウォール型深 
層取水工においては、そのゲートがょり軽い水（上層及び中間層）を塞き止めるので、ゲート近くの中間層は

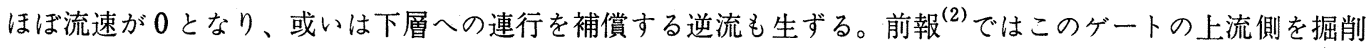
し、水深の $1 \sim 5$ 倍上流に段落ちを設けた場合の上層水の混入率及び流況を比較検討したが、ゲートと段落 ちがこのように近接していると、ゲートによる中間層と下層との境界面の傾斜の効果 ${ }^{(1)}$ と段落ち部に起因する 自由噴流境界、内部跳水が内部境界面に及ぼす影響が重なり合い複雑な流況を呈するので、今回はゲートと段 落ち (斜面の場合はその下端)までの距離を $265 \mathrm{~cm}$ とし、前述の二つの影響を分離して特に段落ち部での密度 流の流況に着目して実験を実施しその結果を解析した。なお上層下層の密度は各々 $\rho_{1}=1.000 \mathrm{~g} / \mathrm{cm}^{3} 、 \rho_{2}=$ $1.016 \mathrm{~g} / \mathrm{cm}^{3}$ 、ゲートの開口高は $6 \mathrm{~cm}$ 、実験開始時の上層厚さは $10 \mathrm{~cm}$ 、下層厚さは段落ち上流で $3.5 \mathrm{~cm}$ 、段 落ち高さは $5 \mathrm{~cm}$ とし、直角段落ちと $1 / 3$ の勾配を有する斜面の 2 ケースについて実験した。鋭い境界面をも って成層させた密度流の下層水をポンプで偱環させると、(典型的な場合として段落ち上流で平均流速を $6.3 \mathrm{~cm} / \mathrm{sec}$ とした) 段落ち付近で下層水の流況は本質的に非定常な様相を呈する。即ち勾配 $1 / 3$ の傾斜面段落ちを例に とると段落ち下流での等密度線が図 $3-1$ のようにほぼ水平になり、下層水もこれに沿い段落ち通過後もし ばらく水平に流れ続ける状態と、図 3-2のように等密度線か段落ちに沿って下降し、下層流もこの中間層 の下を潜って流下する状態とが交互に繰り返されることが観測される。それぞれの状態の継続時間は水平に 流れている時間が 20 30分、潜り込んで流れる時間が10分、これらの間を遷移するのに 10 15分を要する。 直角段落ちの場合にはこれらがもっと短く、水平の状態が 10 分、潜り込みの状態が 5 分、遷移に要するのは やはり10〜15分という結果が出ている。図 3-2の $\rho=1.015 \mathrm{~g} / \mathrm{cm}^{3}$ の等密度線は図に記入されているよりも 下流で生ずる内部跳水のために再び高さを回復する。つまり図 3-2で段落ち直下流で厚くなっている中間 層は流下方向の長さ $30 \mathrm{~cm}$ 程度の局所的な構造である。

さてこれらの時間的に相互に繰り 返される二つの流れのパターンはそ の継続時間の長さから見ても各々可 成安定な状態である。これら二つの 状態間の遷移のうち、水平な流れが 潜り込み流れに遷移する方は段落ち 部及びその上流で生成された上層と 下層の中間の密度をもった成分が溜 ることによって起ることと理解でき るが、その逆の潜り込み流れの水平 な流れへの遷移は何らかの機構によ って図 3-2の段落ち直下流部に発 達した中間層が下流へ流し去られて いる事実を示唆しているが何がこの 状態の継続時間を定め又何が遷移の 引き金 (trigger) となっているのか 今の所明らかでない。

図3-3 と図 3-4 は各々 $1 / 3$ 勾配 の傾斜面段落ちと直角段落ちの、とも に水平な流れの状態での平均流速と 10 秒間の平均流速からの流速の摇らぎの 二乗平方根の平均を図示したものである。

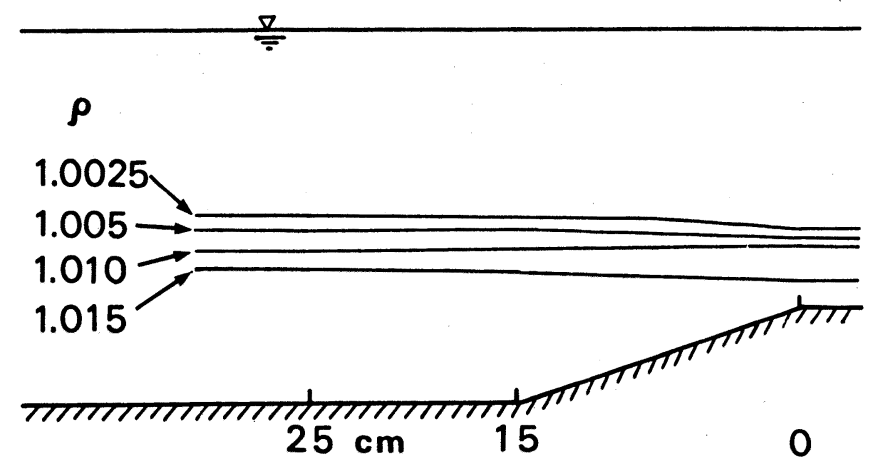

図 3-1 段落ちを通過する密度流の等密度線（水平流れ）

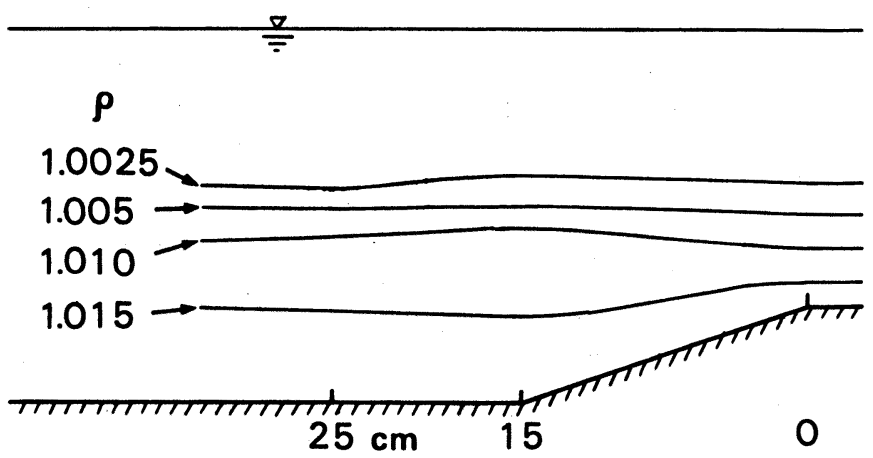

図 3-2 段落ちを通過する密度流の等密度線（潜り込み流れ） 
図を見ると上層と中間層との境界面及び段落ちのエッジの下流側に摇らぎ(乱れ)のレベルの高い層が存在す るのが分り、前者は密度勾配の大きい層の内部波、後者は自由噴流境界に対応すると考之られる。両図の摇 らぎのレベルの高い位置のうち数点 $(\mathrm{A} \sim \mathrm{H})$ でホット・フィルム型流速計で測った流速の時系列をスペクト ル解析すると、傾斜面段落ちのケースでは $\mathrm{A} \sim \mathrm{D} の$ 各点における流速のスペクトル密度の形の間に明確な関連 性が見られなかった。即ちAでは卓越周期が見られず、Bでは1.6sec、Cでは $6.25 \mathrm{sec}$ と0.9sec、Dでは0.16secの 卓越周期が存在する。直角段落ちのケースでは $\mathrm{E} 、 \mathrm{~F} 、 \mathrm{H}$ の各点で $1.4 \mathrm{sec}(\mathrm{G} の み 1.25 \mathrm{sec}$ と $3.3 \mathrm{sec})$ といj 共通の卓越周期が現れている。これは図 $3-1$ から $\rho^{-1} \cdot d \rho / d z \simeq 4.5 \times 10^{-3}$ で定 まる Brunt-Väisälä 振動数 $N=3.9 \mathrm{rad} / \mathrm{sec} \Delta \overline{\mathrm{u}} \cdots 1 \mathrm{~cm} / \mathrm{s}$ $(T=2 \pi / N=1.6 \mathrm{sec})$ に対応する波動であ るとみられる。 $\mathrm{A}$ 及び $\mathrm{E} に$ 対応する地点 では、水平流から潜り込み流れに遷移す る前兆として径 $1 \mathrm{~cm}$ 程の渦が境界面上に 発生し上層流体が下層流体と混合し中間 層の生成がなされる。上の周期 $1.4 \mathrm{sec}$ はこの渦の発生周期とほぼ一致している。 又乱れの相対的レベルは図 $3-4$ の直角 段落ちょりも図 $3-3$ の傾斜面段落ちの 方が低く、これが両者の混入率の差に影 響を与えている一つの因子であることが 分る。(2)

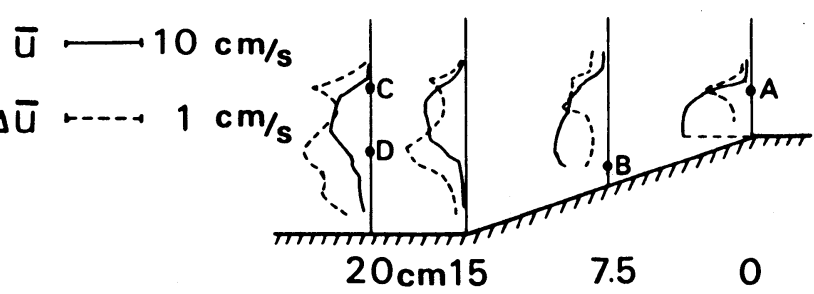

図 3-3 傾斜面段落ちを通過する密度流の平均流速 $\bar{u}$ と摇 らぎの二乗平方根の平均 $\Delta \overline{\mathrm{u}}$ (水平流れ)

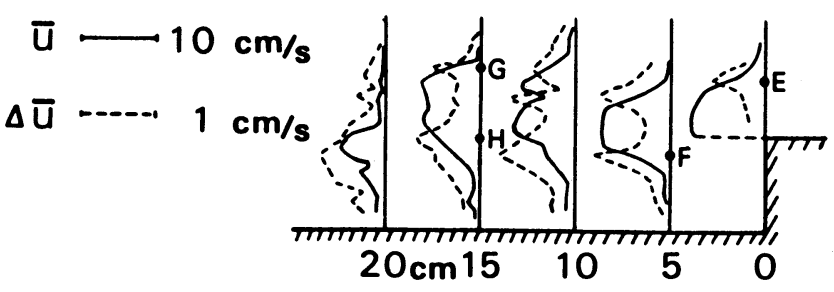

図 3-4 直角段落ちを通過する密度流の平均流速 $\bar{u}$ と摇ら ぎの二乗平方根の平均 $\Delta \bar{u}$ (水平流れ)

\section{4 、噴流境界の幅に関する次元解析}

図 4-1のように平板に沿う一様流が平板の下流端で半無 限の静止流体と接触して生じる流れ（自由噴流境界）につい ては Liepmann、Laufer の実験 ${ }^{(10)}$ が流れの相似性と噴流の幅 が流下距離 $\boldsymbol{x}$ に比例することを示していることもあり、これ に関する次元解析の理論も初めからそれを仮定したもの やそれと矛盾しない理論 ${ }^{(13)}$ が発表されている。他方 slit から 噴出する二次元噴流の次元解析では、Görtler ${ }^{(11)}$ は噴流の幅 $b(x)$ と流速 $u(x)$ の $x$ 方向の変化の 2 つのべキ指数を未知と して、これを $x$ 方向に圧力勾配がないために $x$ 方向の全運動

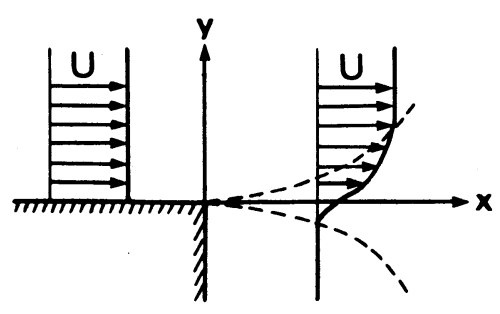

図 4-1 二次元自由噴流境界 量輸送が一定であることと境界層方程式から定め、この場合 噴流の幅は $x$ に比例して增大することを示している。ここで は、それと全く同様な方法を図 4-1の自由噴流境界に適用した結果について述べる。

噴流は定常であるとすると境界層方程式は次の通りである。

$$
u \frac{\partial u}{\partial x}+v \frac{\partial u}{\partial y}=\frac{1}{\rho} \frac{\partial \tau}{\partial y}
$$

又、自由乱流において一般的に用いられる渦動粘性応力に関するPrandtl の仮説を用いる。

$$
\tau=k b(x)\left(u_{\max }(x)-u_{\min }(x) \frac{\partial u}{\partial y}\right.
$$

この場合断面内の最大最小流速は $x$ によらず一定である。 


$$
u_{\max }(x)=U, \quad u_{\min }(x)=0
$$

噴流の幅 $b(x)$ が $x$ の $m$ 乗に比例するとすると $x=s$ での幅 $b_{s}$ を用いて次のように表わせる。

$$
b(x)=b_{s}\left(\frac{x}{s}\right)^{m}
$$

流下方向に垂直な断面内での流速分布は相似であると仮定すると、流函数 $\Psi(x, y)$ を

$$
\Psi(x, y)=f(x) \psi(\eta) \quad, \quad \eta=y / b(x)
$$

と表わすことができる。又、 $f(x)$ が $x$ の $p$ 乗に比例すると仮定すると

$$
f(x)=b_{s} U\left(\frac{x}{s}\right)^{p}
$$

と書け、これより $u 、 v$ 及びその微分、更に $\tau$ の $x$ に関するべキ $(x$ との函数とみたときの)が定まる。

$$
u \frac{\partial u}{\partial x} \sim x^{2 p-2 m-1}, \quad \frac{\partial^{2} u}{\partial y^{2}} \sim x^{p-3 m}
$$

これらを境界層方程式 $(4-1)$ に代入すると $x$ のべキ指数の間には次の関係が成立せねばならないことが分る。

$$
2 p-2 m-1=m+(p-3 m)
$$

ゆえに $p=1$ である。

$x$ 方向の全運動量輸送が $x$ によらず一定である条件は次のように書ける。

$$
\begin{aligned}
J & =\rho \int_{-\infty}^{\infty} b(x) u^{2}(x, \eta) d \eta \\
& =\rho \frac{f^{2}(x)}{b(x)} \int_{-\infty}^{\infty}\left\{\psi^{\prime}(\eta)\right\}^{2} d \eta=\text { const. }
\end{aligned}
$$

これから $p$ との間に次の関係式を得る。

$$
2 p-m=0
$$

こうして噴流の幅 $b(x)$ の $x$ に関するべキ指数 $m$ は 2 であることが導かれる。この様子を図示したものが図 4 一 1 の破線である。尤も噴流の幅 $b(x)$ が $x^{2}$ に比例して大きくなるということは単に二つの破線間の距離が $x^{2}$ に比例することを示しているのであるから二つの破線各々が放物線であることを主張するものではなく困 とは異なる形状もとりうる。しかし二つの破線の両方ともが直線にならないという結果が出たわけである。

著者らの行った実験は鉛直方向上方は内部境界により又下方は底面により限定されているのでこの解析の条 件とは異なる要素を含んでおり、一方実験精度上からも噴流幅の函数形を定めることは難しい。

\section{5.むすび}

海底地形急変部、特に段落ち付近での密度流境界面に関連した諸問題を実験に即して或いは理論的方法に より解析したが、実験に関しては段落ち下流での潜り込み流れの継続時間が短いことや密度流そのものが外 的条件の些細な変化に微妙に影響を受ける性質を有しているために十分な解析がなされておらず、今後詳し く研究してゆかなければならない。また各節に述べられた内容が必ずしも有機的に総合されているとはいえ ず、上記の点と相俟って今後に残された課題である。

\section{6. 謝 辞}

東京理科大学土木工学教室 西村司氏には実験の実施に当り御助力を戴いた。また同教室水理研究室の卒 
業研究の学生諸君には実験及びデー夕、図面の整理などに協力して載いた。図 $2-4$ のデータは㑊厂イ・エ ヌ・エー新土木研究所宮崎洋三氏より提供を受けた。ここに記して謝意を表する次第である。

\section{7. 参考文献}

(1)柴田正和、大西外明：密度流の境界面の安定性——傾斜境界面に沿う加速流について—第22回水理講演 会論文集、87、1978.

(2)大西外明、宮崎洋三、柴田正和 : 冷却水選択取水に及ぼす海底地形の影響、第25回海岸工学講演会論文集、 490、1978.

(3)Harleman, D. R. F., Gooch, R. S., Ippen, A. T. : Submerged sluice control of stratified flow, Proc. ASCE, 84, HY2, 1584, 1958.

(4)千秋信一：火力発電所冷却水深層取水工の水理設計、発電火力、92、9、1968.

(5)水理委員会密度流小委員会：成層密度流の界面現象(1)、土木学会論文報告集、242、73、1975.

(6)Chadrasekhar, S. : Hydrodynamic and Hydromagnetic Stability, Clarendon Press, 1961.

(7)Thorp, S. A. : Experiments on the instability of stratified shear flows; immiscible fluids,

J. Fluid Mech., 39, 25, 1969.

(8)Thorp, S. A. : Experiments on the instability of stratified shear flows; miscible fluids, J. Fluid Mech. , 46, 299, 1971.

(9)Turner, J. S. : Buoyancy Effects in Fluids, Cambridge University Press, 1973.

(10)Liepmann, H. W., Laufer, J. : Investigation of free turbulent mixing, NACA Tech. Note, 1257, 1947.

(11)Görtler, voǹ H., Berechnung von Aufgaben der frien Turbulenz auf Grund eines neuen

Näherungs ansatzes, ZAMM, 22, 244, 1942.

(12)Schlichting, H. : Boundary Layer Theory, sixth edition, McGraw Hill, 1968.

(13)Rajaratnam, N. : Turbulent Jets, Elsevier, 1976. 